\title{
Effect of Partially Substituting Ca with Mischmetal on the Microstructure and Mechanical Properties of Extruded $\mathrm{Mg}-\mathrm{Al}-\mathrm{Ca}-\mathrm{Mn}$-Based Alloys
}

\author{
Chao Xu ${ }^{1} \cdot$ Taiki Nakata $^{2} \cdot$ Guo-Hua Fan ${ }^{1} \cdot$ Kosuke Yamanaka $^{2} \cdot$ Guang-Ze Tang $^{1} \cdot$ Lin Geng $^{1} \cdot$ \\ Shigeharu Kamado
}

Received: 12 July 2018/Revised: 28 August 2018/Published online: 19 September 2018

(C) The Chinese Society for Metals and Springer-Verlag GmbH Germany, part of Springer Nature 2018

\begin{abstract}
Mg-2Al-1.2Ca-0.2Mn (at\%)-based alloys with Ce-rich mischmetal (MM) substitution of 0-0.6 at\% for Ca were hot extruded at $400{ }^{\circ} \mathrm{C}$. The effect of MM substitution on the microstructure and mechanical properties of the extruded alloys was investigated. The as-cast $\mathrm{Mg}-2 \mathrm{Al}-1.2 \mathrm{Ca}-0.2 \mathrm{Mn}$ alloy is mainly composed of $\alpha-\mathrm{Mg}, \mathrm{Mg}_{2} \mathrm{Ca}$ and $(\mathrm{Mg}, \mathrm{Al})_{2} \mathrm{Ca}$ phases and $\mathrm{Al}_{8} \mathrm{Mn}_{5}$ precipitates, whereas the substitution of $\mathrm{MM}$ brings about the formation of $\mathrm{Al}_{11} \mathrm{MM}_{3}, \mathrm{Al}_{2} \mathrm{MM}$ phases and $\mathrm{Al}_{10} \mathrm{MM}_{2} \mathrm{Mn}_{7}$ particles with the absence of $(\mathrm{Mg}, \mathrm{Al})_{2} \mathrm{Ca}$ phase. The volume fraction of MM-containing phases increases with increasing $\mathrm{MM}$ contents. All of the extruded alloys exhibit bimodal microstructure comprising fine dynamically recrystallized grains with almost random orientation and coarse deformed grains with strong basal texture. Dense nanosized planar $\mathrm{Al}_{2} \mathrm{Ca}$ and spherical $\mathrm{Al}-\mathrm{Mn}$ phases precipitate inside the deformed grains. High tensile yield strengths of $\sim 350 \mathrm{MPa}$ and moderate elongations to failure of $>12 \%$ are obtained in all extruded alloys; the MM substitution induces negligible difference in the tensile properties at ambient temperature, while the highest MM substitution improves the strength at $180{ }^{\circ} \mathrm{C}$ due to the better thermal stability of the fragmented MM-containing phases.
\end{abstract}

Keywords Magnesium alloys · Extrusion · Microstructures · Precipitation · Mechanical properties

\section{Introduction}

In recent years, with increasing demands for weight reduction in the transportation vehicles to reduce the $\mathrm{CO}_{2}$ emission and improve the fuel efficiency, $\mathrm{Mg}$ and its alloys have been becoming attractive as structural materials due to their low density, high specific strength, easy recyclability and so on [1-4]. However, the high-temperature powertrain components and engine parts generally operate at $150-200{ }^{\circ} \mathrm{C}[5,6]$, and the poor heat resistance of the

Available online at http://link.springer.com/journal/40195

Chao Xu

cxu@hit.edu.cn

$\triangle$ Guang-Ze Tang oaktang@hit.edu.cn

1 School of Materials Science and Engineering, Harbin Institute of Technology, Harbin 150001, China

2 Department of Mechanical Engineering, Nagaoka University of Technology, Nagaoka 940-2188, Japan conventional $\mathrm{Mg}-\mathrm{Al}$-based alloys such as AZ91, AM60 caused by the formation of $\beta-\mathrm{Mg}_{17} \mathrm{Al}_{12}$ phase makes them incompetent to be used at above $120{ }^{\circ} \mathrm{C}$ and limits their practical applications [7-11]. It was found that the addition of low-cost $\mathrm{Ca}$ to the $\mathrm{Mg}-\mathrm{Al}$ alloys results in the formation of thermally stable Laves phases such as $\mathrm{Mg}_{2} \mathrm{Ca}$ (C14, hexagonal), ( $\mathrm{Mg}, \mathrm{Al})_{2} \mathrm{Ca}$ (C36, dihexagonal), $\mathrm{Al}_{2} \mathrm{Ca}(\mathrm{C} 15$, cubic) and precipitation strengthening by monolayer Guinier-Preston (GP) zones [12-19], which significantly improve the high-temperature strength and creep resistance of the alloys.

It is known that MM (Ce-rich mischmetal) addition to $\mathrm{Mg}-\mathrm{Al}$-based alloys induces the formation of thermally stable $\mathrm{Al}_{11} \mathrm{MM}_{3}$ and $\mathrm{Al}_{2} \mathrm{MM}$ phases [17, 20], and the combined additions of $\mathrm{Ca}$ and $\mathrm{MM}$ (Ce-rich mischmetal) to the $\mathrm{Mg}-\mathrm{Al}$-based alloys further improve the heat resistance by the segregation of solute atoms at the grain boundaries and the formation of not only thermally stable $\mathrm{Al}_{11} \mathrm{MM}_{3}$, $\mathrm{Al}_{2} \mathrm{MM}$ phases but also $\mathrm{Al}-\mathrm{Ca}$ phases [21-26]. Besides, the $\mathrm{Mn}$ addition to $\mathrm{Mg}-\mathrm{Al}-\mathrm{Ca}$ alloy enhances the corrosion resistance [27] and considerably improves the creep 
resistance due to the precipitation of nanosized Al-Mn phases, increased number density of GP zones and enhanced solution strengthening by the supersaturated $\mathrm{Ca}$ atoms in the $\alpha-\mathrm{Mg}$ matrix $[28,29]$. Therefore, $\mathrm{Mg}-\mathrm{Al}-\mathrm{Ca}-$ MM-Mn alloys become promising for the high-strength and heat-resistant $\mathrm{Mg}$ products as engine components. It is noted that the $\mathrm{Ca} / \mathrm{Al}$ and $\mathrm{MM} / \mathrm{Al}$ ratios determine the formation of $\mathrm{Al}-\mathrm{Ca}$ and $\mathrm{Al}-\mathrm{MM}$ phases $[12,30]$, so that the variety and proportions of the $\mathrm{Al}-\mathrm{Ca}$ and $\mathrm{Al}-\mathrm{MM}$ phases in the $\mathrm{Mg}-\mathrm{Al}-\mathrm{Ca}-\mathrm{MM}-\mathrm{Mn}$ alloys depend on the $\mathrm{Ca}, \mathrm{MM}$ contents and their ratios to $\mathrm{Al}$. However, it has been rarely reported until now.

Hot extrusion is an effective way to eliminate the cast defects such as porosity, breakup of the large eutectic compounds located at the grain boundaries, refining of the microstructure and improving the mechanical properties of $\mathrm{Mg}$ alloys [31-36]. Therefore, in this study, $\mathrm{Mg}-\mathrm{Al}-\mathrm{Ca}-$ Mn-based alloys with partial substitution of $\mathrm{MM}$ for $\mathrm{Ca}$ were hot extruded in order to develop high-strength and heat-resistant $\mathrm{Mg}$ alloys, and the effect of the substitution with various $\mathrm{MM} / \mathrm{Ca}$ ratios on the microstructure and tensile properties at ambient and elevated temperature of the extruded alloys was investigated.

\section{Experimental}

The Mg-2Al-1.2(Ca $+\mathrm{MM})-0.2 \mathrm{Mn}$ alloy billets with MM substitution content of $0,0.2,0.4$ and $0.6 \%$ (all concentration in at $\%$, unless otherwise stated and denoted as AX212, AXE2102, AXE20804 and AXE20606, respectively) analyzed in this study were fabricated by direct chill casting. Melting was conducted at $720^{\circ} \mathrm{C}$ in an electric furnace in a mixed gas atmosphere of $\mathrm{SF}_{6}$ and $\mathrm{CO}_{2}$, using pure $\mathrm{Mg}$ and $\mathrm{Al}$ with purity higher than $99.95 \mathrm{wt} \%$, and $\mathrm{Al}-$ $10 \mathrm{wt} \% \mathrm{Mn}, \mathrm{Mg}-30 \mathrm{wt} \% \mathrm{Ca}$ as well as $\mathrm{Mg}-20 \mathrm{wt} \% \mathrm{MM}$ master alloys. Subsequently, direct chill casting was performed and the chemical compositions of the billets are presented in Table 1. The billets were cut and machined to cylindrical samples with $43 \mathrm{~mm}$ in diameter and $37 \mathrm{~mm}$ in length for extrusion, then preheated at $400{ }^{\circ} \mathrm{C}$ for $5 \mathrm{~min}$ prior to the extrusion. Subsequently, indirect extrusion was performed at $400{ }^{\circ} \mathrm{C}$ with an extrusion ratio of 20:1 and a ram speed of $0.1 \mathrm{~mm} / \mathrm{s}$. Finally, cylindrical rods with $9.6 \mathrm{~mm}$ in diameter and $500 \mathrm{~mm}$ in length were obtained.

Olympus BX60M optical microscope (OM) and JEOL JSM-7000F field-emission scanning electron microscope (FE-SEM) equipped with an energy dispersive X-ray spectroscope (EDX) operated at $15 \mathrm{kV}$ was used to observe the microstructure of the as-cast and as-extruded alloys. The samples were sectioned and ground using emery papers up to \#4000 then mechanically polished and followed by etching in the picric acid. The texture was examined by an EDAX-TSL electron back-scattered diffraction (EBSD) system operating at $25 \mathrm{kV}$, and the data were analyzed by OIM Analysis software. Transmission electron microscope (TEM) was carried out on a JEOL JEM-2100F operating at $200 \mathrm{kV}$. Thin foils for TEM observation with thickness of $0.2 \mathrm{~mm}$ were cut from the center of the as-cast billets and as-extruded rods, then they were punched into disks with $3 \mathrm{~mm}$ in diameter and mechanically polished followed by low-angle ion milling using Gatan precision ion-polishing system.

The tensile specimens having a gauge length of $22 \mathrm{~mm}$ and a diameter of $4 \mathrm{~mm}$ were machined from the as-extruded rods. The tensile direction was parallel to the extrusion direction (ED), and the tensile tests were conducted on a Shimadzu Autograph AG-I $(50 \mathrm{kN})$ machine at an initial strain rate of $1 \times 10^{-3} \mathrm{~s}^{-1}$ at room temperature (RT) and $180{ }^{\circ} \mathrm{C}$. Tensile test at both RT and $180^{\circ} \mathrm{C}$ was performed 3 times for each extruded alloy.

\section{Results and Discussion}

\subsection{Microstructure of the As-Cast Alloys}

Figure 1 shows the optical micrographs of the as-cast alloys with different MM substitution contents, which suggests that all of the alloys exhibit a dendritic microstructure with $\alpha-\mathrm{Mg}$ matrix, eutectic phases and some small particles dispersed in the interdendritic regions. The majority of the network-shaped eutectic phases with black contrast in the AX212 distribute continuously in the $\alpha-\mathrm{Mg}$ matrix, as shown in Fig. 1a. According to secondary electron image (SEI) and EDX elemental mappings obtained from the AX212 shown in Fig. 2a, Al and Ca
Table 1 Chemical compositions in at $\%$ and $w t \%$

\begin{tabular}{|c|c|c|c|c|c|c|c|c|c|c|}
\hline \multirow[t]{2}{*}{ Alloy } & \multicolumn{5}{|l|}{ at $\%$} & \multicolumn{5}{|l|}{ wt $\%$} \\
\hline & $\mathrm{Al}$ & $\mathrm{Ca}$ & $\mathrm{RE}$ & Mn & $\mathrm{Mg}$ & $\mathrm{Al}$ & $\mathrm{Ca}$ & $\mathrm{RE}$ & $\mathrm{Mn}$ & $\mathrm{Mg}$ \\
\hline AX212 & 1.75 & 0.94 & - & 0.17 & Bal. & 1.92 & 1.54 & - & 0.37 & Bal. \\
\hline AXE2102 & 1.58 & 0.75 & 0.20 & 0.14 & Bal. & 1.72 & 1.21 & 1.09 & 0.30 & Bal. \\
\hline AXE20804 & 1.8 & 0.7 & 0.37 & 0.16 & Bal. & 1.93 & 1.06 & 2.04 & 0.35 & Bal. \\
\hline AXE20606 & 1.77 & 0.47 & 0.64 & 0.15 & Bal. & 1.89 & 0.74 & 3.62 & 0.33 & Bal. \\
\hline
\end{tabular}



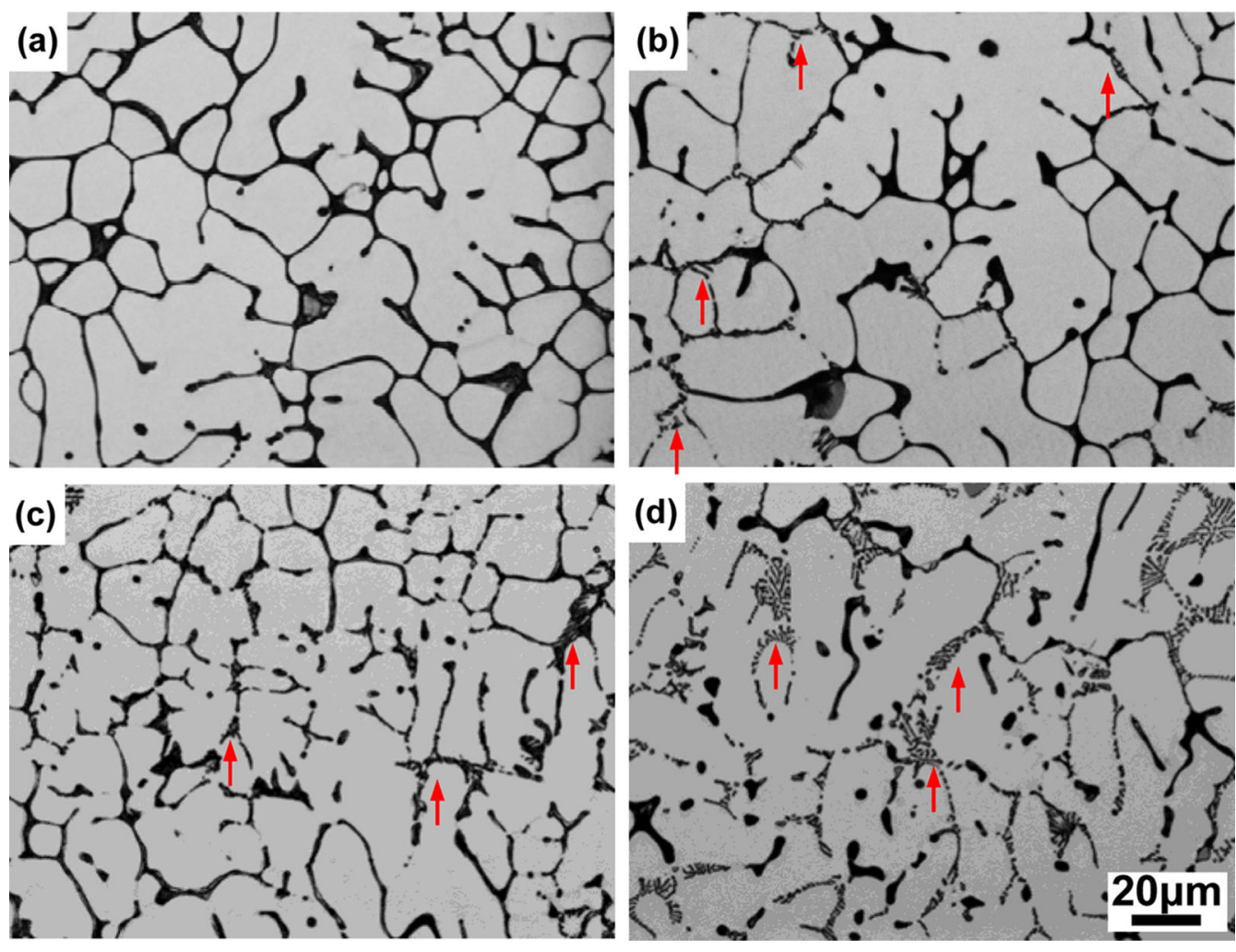

Fig. 1 Optical micrographs of the as-cast alloys: a AX212, b AXE2102, c AXE20804, d AXE20606

atoms enrich in the eutectic phases. The particles dispersed in the interdendritic regions are mainly composed of $\mathrm{Al}$ and Mn elements, which should be $\mathrm{Al}_{8} \mathrm{Mn}_{5}$ phases commonly observed in $\mathrm{Mg}-\mathrm{Al}-\mathrm{Ca}-\mathrm{Mn}$ alloys [37].

The substitution of $0.2 \% \mathrm{MM}$ for Ca results in the formation of acicular eutectic phases in the AXE2102 as marked by red arrows in Fig. 1b-d which reveals that accompanied with increasing MM substitution contents, the morphology of the grain boundary phases becomes divorced and the area fraction of coarse acicular phases (indicated by red arrows) increases gradually. It is noted that the area fraction of the phases in the AXE2102 is lower than those in other three alloys, which should be caused by the composition deviation as shown in Table 1 . Figure $2 b$ shows the SEI and EDX elemental mappings taken from the phases in the AXE20606; it can be seen that the Mg, Al, and $\mathrm{MM}$ atoms concentrate in the coarse acicular phases with white contrast (indicated by red arrows in SEI image), while the eutectic phases with gray contrast (indicated by blue arrows in SEI image) are mainly composed of $\mathrm{Mg}$ and $\mathrm{Ca}$; the distribution of $\mathrm{Al}$ becomes faint which is different from those in the AX212. Additionally, one large particle enriched with $\mathrm{Al}, \mathrm{Mn}$ and $\mathrm{MM}$ can be significantly recognized. It is reported that the MM addition to the $\mathrm{Mg}-\mathrm{Al}-$ $\mathrm{Mn}$ alloys leads to the precipitation of $\mathrm{Al}_{10} \mathrm{MM}_{2} \mathrm{Mn}_{7}$ phase with trigonal structure rather than the $\mathrm{Al}_{8} \mathrm{Mn}_{5}$ phase
[38-40], which agrees well with the element constitution of the particle observed in Fig. $2 \mathrm{~b}$, and so that the particle should be $\mathrm{Al}_{10} \mathrm{MM}_{2} \mathrm{Mn}_{7}$ phase.

TEM was utilized to analyze the crystal structures of the eutectic phases in the as-cast alloys. Figure $3 a$, b shows the bright field (BF) images and selected area electron diffraction (SAED) patterns taken from the eutectic phases with fine and coarse lamellar structures in the AX212, based on the SAED patterns with incident beam parallel to the [11 $\overline{2} 0]$ and [0001] of the $\alpha-\mathrm{Mg}$, the phases are identified to be $\mathrm{Mg}_{2} \mathrm{Ca}$ with $\mathrm{C} 14$ structure and $(\mathrm{Mg}, \mathrm{Al})_{2} \mathrm{Ca}$ with $\mathrm{C} 36$ structure, respectively $[12,29]$. Accordingly, AX212 is composed of network-shaped $\mathrm{Mg}_{2} \mathrm{Ca}$ and $(\mathrm{Mg}, \mathrm{Al})_{2} \mathrm{Ca}$ phases, and scattered $\mathrm{Al}_{8} \mathrm{Mn}_{5}$ particles. The average interlamellar spacing of the $\mathrm{Mg}_{2} \mathrm{Ca}$ and $(\mathrm{Mg}, \mathrm{Al})_{2} \mathrm{Ca}$ phases is calculated to be $0.15 \mu \mathrm{m}$ and $0.2 \mu \mathrm{m}$, respectively. Thus, they can hardly be distinguished with each other by morphology in the optical micrograph (Fig. 1a) because of the little difference.

The TEM BF images and corresponding SAED patterns of the fine lamellar and coarse acicular phases in the AXE20606 are shown in Fig. 3c, d, which suggest that the fine lamellar phase has the same $\mathrm{C} 14$ structure with those observed in the AX212 and should be $\mathrm{Mg}_{2} \mathrm{Ca}$ phase. Figure $3 \mathrm{~d}$ shows that the acicular phases and adjacent polygonal phase are determined to be $\mathrm{Al}_{11} \mathrm{MM}_{3}$ with body- 

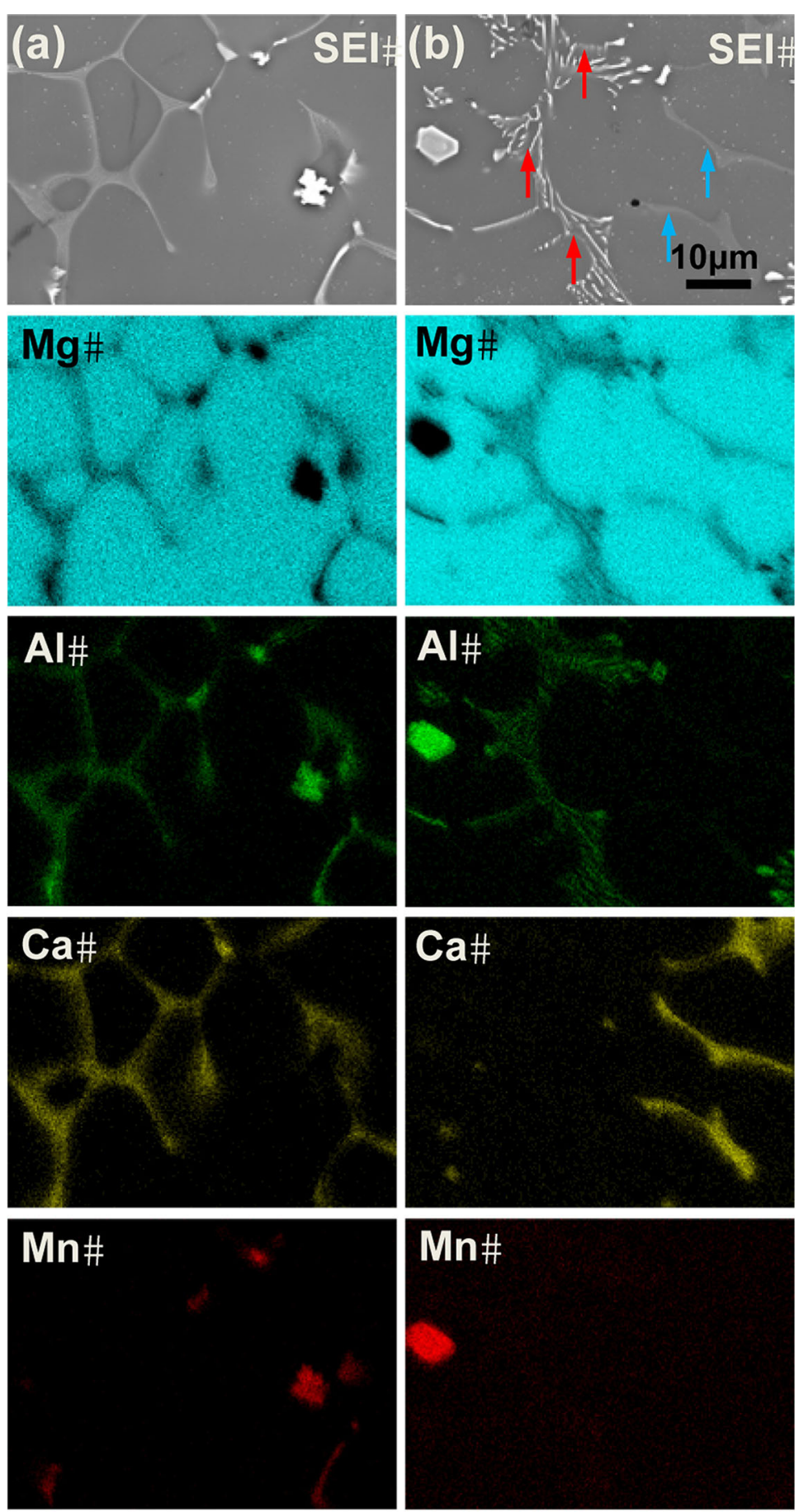

\section{MM\#}

Fig. 2 EDX elemental mapping analysis of Mg, Al, Ca, Mn, and MM in the as-cast alloys. a AX212 and b AXE20606 

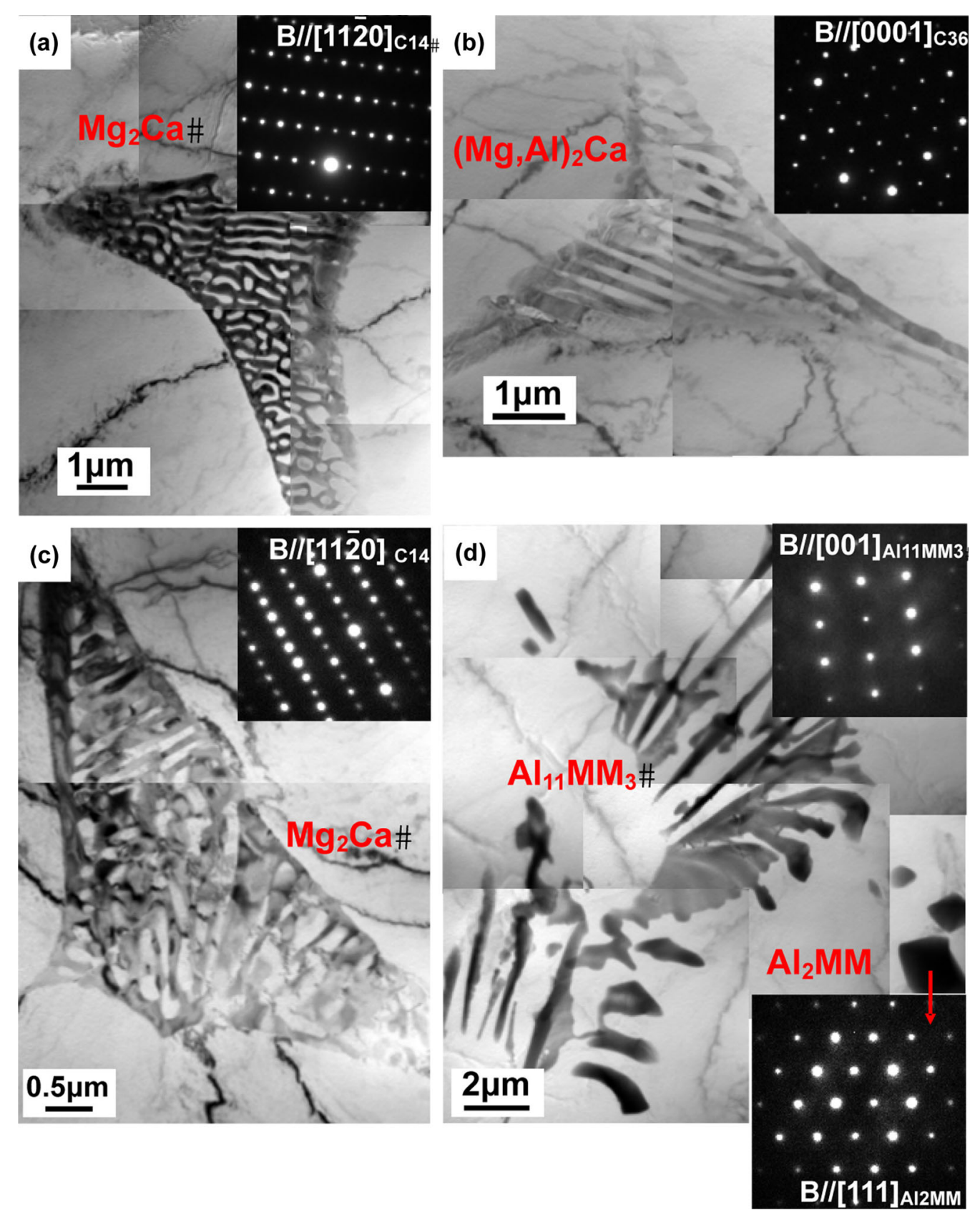

Fig. 3 TEM BF images and corresponding SAED patterns taken from the eutectic compounds in the as-cast AX212 and AXE20606 alloys: a $\mathrm{Mg}_{2} \mathrm{Ca}$ with $\mathrm{C} 14$ structure and $\mathbf{b}(\mathrm{Mg}, \mathrm{Al})_{2} \mathrm{Ca}$ with $\mathrm{C} 36$ structure in $\mathrm{AX} 212, \mathbf{c} \mathrm{Mg}_{2} \mathrm{Ca}$ with $\mathrm{C} 14$ structure and $\mathbf{d} \mathrm{Al}_{11} \mathrm{MM}$ and $\mathrm{Al} \mathrm{M}_{2} \mathrm{MM}_{\text {with }}$ bco and fcc structures, respectively, in AXE20606

centered orthorhombic (bco) structure and $\mathrm{Al}_{2} \mathrm{MM}$ with face-centered cubic (fcc) structure, respectively [41, 42]. Since the average lamellar spacing of $\mathrm{Al}_{11} \mathrm{MM}_{3}$ phases $(1.2 \mu \mathrm{m})$ is 8 times larger than that of the $\mathrm{Mg}_{2} \mathrm{Ca}(0.15 \mu \mathrm{m})$ in the AXE20606, they can be easily distinguished in the optical micrograph (Fig. 1d). The different morphologies of the eutectic phases may be resulted from the different crystal structures and partitioning of solute atoms between $\alpha-\mathrm{Mg}$ matrix and the phases [12]. Additionally, the scattered particles in the AXE20606 (Fig. 1d) should be composed of $\mathrm{Al}_{10} \mathrm{MM}_{2} \mathrm{Mn}_{7}$ and $\mathrm{Al}_{2} \mathrm{MM}$ phases simultaneously due to the similar morphology.

The composition of the AX212 in this study is located in the tie-triangle of $\mathrm{Mg}-\mathrm{Al}-\mathrm{Ca}$ ternary phase diagram estimated by Suzuki et al. [12] in which two eutectic transformations occur: $\mathrm{L} \rightarrow \alpha-\mathrm{Mg}+(\mathrm{Mg}, \mathrm{Al})_{2} \mathrm{Ca}$ and $\mathrm{L} \rightarrow \alpha$ $\mathrm{Mg}+\mathrm{Mg}_{2} \mathrm{Ca}+(\mathrm{Mg}, \mathrm{Al})_{2} \mathrm{Ca}$; thus, the alloys with the composition inside that tie-triangle should consist of $\alpha-\mathrm{Mg}$, $\mathrm{Mg}_{2} \mathrm{Ca}$ and $(\mathrm{Mg}, \mathrm{Al})_{2} \mathrm{Ca}$ phases, which is in good accordance with the experimental result of the AX212. More 
recently, Janz et al. [43] also developed a thermodynamic modeling of the $\mathrm{Mg}-\mathrm{Al}-\mathrm{Ca}$ system and the composition of AX212 also located in the three-phase tie-triangle with $\alpha$ $\mathrm{Mg}, \mathrm{Mg}_{2} \mathrm{Ca}$ and $(\mathrm{Mg}, \mathrm{Al})_{2} \mathrm{Ca}$ of the isothermal phase diagram section at $500{ }^{\circ} \mathrm{C}$, while according to the isothermal section below $400{ }^{\circ} \mathrm{C}$, the $(\mathrm{Mg}, \mathrm{Al})_{2} \mathrm{Ca}$ phase should transform to the $\mathrm{Al}_{2} \mathrm{Ca}$ phase, which is distinct from the result in this study. Meanwhile, it is reported that the $(\mathrm{Mg}, \mathrm{Al})_{2} \mathrm{Ca}$ phase is expected to be formed in the fast cooling $\mathrm{Mg}-\mathrm{Al}-\mathrm{Ca}$ alloys and only the low cooling rate engages the formation of low-temperature equilibrium $\mathrm{Al}_{2} \mathrm{Ca}$ phase [16]. It should be mentioned that the cooling rate of the alloys in the research of Janz et al. is merely $1{ }^{\circ} \mathrm{C} /$ min that is much lower than $100-110^{\circ} \mathrm{C} / \mathrm{s}$ of the direct chill casting method [34] used in this study; thus, the phase constitution of the AX212 is reasonable due to the deviated solidification path from the phase diagram calculated based on the equilibrium solidification.

The 0.6\% MM substitution for Ca brings about high area fraction of MM-containing phases in the AXE20606, meanwhile the $\mathrm{Mg}_{2} \mathrm{Ca}$ phase is also observed but with the absence of $(\mathrm{Mg}, \mathrm{Al})_{2} \mathrm{Ca}$ phase. It is known that the enthalpy of mixing between $\mathrm{Al}$ and $\mathrm{Ca}$ is $-20 \mathrm{~kJ} / \mathrm{mol}, \mathrm{Mg}$ and $\mathrm{MM}$ is $-7 \mathrm{~kJ} / \mathrm{mol}, \mathrm{Mg}$ and $\mathrm{Ca}$ is $-5.6 \mathrm{~kJ} / \mathrm{mol}$, whereas it is - $39 \mathrm{~kJ} / \mathrm{mol}$ between $\mathrm{Al}$ and MM. As a result, formation of $\mathrm{Al}_{11} \mathrm{MM}_{3}$ and $\mathrm{Al}_{2} \mathrm{MM}$ phases is preferred in comparison with other phases during solidification. If we assume that only $\mathrm{Al}_{2} \mathrm{MM}$ phase forms, then the $\mathrm{Al} / \mathrm{Ca}$ ratio in the remained liquid phase is definitely lower than $4 / 3$. Consequently, the composition of the AXE20606 falls outside of the three-phase tie-triangle and locates in the two-phase region with $\alpha-\mathrm{Mg}$ and $\mathrm{Mg}_{2} \mathrm{Ca}$ phase [12] which well accounts for the absence of the $(\mathrm{Mg}, \mathrm{Al})_{2} \mathrm{Ca}$ phase in the AXE20606.

Figure 4 shows the EBSD results of the as-cast alloys to distinguish the grain size from the dendrite cell size by orientation analysis. It can be seen that, in comparison with the optical micrographs in Fig. 1, the grain sizes are much larger than the cell sizes of the as-cast alloys, and thus, a majority of the grains should contain multiple dendrite cells. Furthermore, the grain size increases gradually with the increasing $\mathrm{MM}$ substitution contents and 0.6\% MM substitution makes the grain size of the AXE20606 two times larger than that of the AX212. It is reported that MM react with $\mathrm{Al}_{8} \mathrm{Mn}_{5}$ or other $\mathrm{Al}-\mathrm{Mn}$ phases to form $\mathrm{Al}_{10-}$ $\mathrm{MM}_{2} \mathrm{Mn}_{7}$ phase which cannot pin the grain boundaries effectively [40,44]. Although the simultaneous addition of $\mathrm{Ca}$ and $\mathrm{MM}$ to the $\mathrm{Mg}-\mathrm{Al}$ alloys refines the $\mathrm{Al}_{11} \mathrm{MM}_{3}$ phases with acicular morphology [45], the $\mathrm{Al}_{11} \mathrm{MM}_{3}$ phases mainly distribute inside the $\alpha-\mathrm{Mg}$ grains rather than at the grain boundaries to pin the grain boundaries. Besides, the distribution of eutectic phases becomes divorced via the MM substitution (Fig. 1), the grain growth cannot be effectively restricted compared with the network-shaped $\mathrm{Mg}_{2} \mathrm{Ca}$ and $(\mathrm{Mg}, \mathrm{Al})_{2} \mathrm{Ca}$ phases in the AX212 and finally, coarsened grain size with increasing $\mathrm{MM}$ substitution contents is obtained. Figure 4 also shows the pole figures of the as-cast alloys and which indicates that no preferential orientation occurs during solidification and MM substitution has no effect on the texture of the as-cast alloys.

\subsection{Microstructure of the As-Extruded Alloys}

Figure 5 shows the SEM micrographs of the as-extruded AX212 and AXE20606. It can be seen that the eutectic phases are fragmented by the severe deformation during hot extrusion with ratio of $20: 1$ and distribute along the ED. Comparing with the AX212, the spacing among the phase distribution bands increases by the $0.6 \%$ MM substitution in the AXE20606. Furthermore, both of the asextruded AX212 and AXE20606 exhibit bimodal microstructure that consists of fine dynamic recrystallized (DRXed) grains and coarse deformed grains stretched along the ED marked by red arrows in Fig. 5a, c, and it is noted that the fragmented phases can rarely be observed in the unrecrystallized regions as indicated by red arrows in Fig. 5. According to the magnified images shown in Fig. 5b, d, the fragmented phases in the as-extruded AX212 are sufficiently broken up to fine polygonal particles with the average diameter of $\sim 0.4 \mu \mathrm{m}$ and densely distribute at the fine DRXed grain boundaries. However, in the AXE20606, the distribution of the fragmented MMcontaining phases with the average size of $\sim 1.3 \mu \mathrm{m}$ is relatively inhomogeneous and most of which exhibit rod morphologies due to the insufficient fracture during extrusion. It is likely related to the coarser acicular morphology of the eutectic phases in the AXE20606, which makes them more difficult to be crushed during extrusion. $\mathrm{Xu}$ et al. [34] also reported that formation of finer lamellar microstructure in the as-cast $\mathrm{Mg}-\mathrm{Al}-\mathrm{Ca}-\mathrm{Mn}$ alloy leads to the finer crushed eutectic particles with more uniform distribution after hot extrusion.

EBSD analysis was performed on the extruded alloys. Figure $6 \mathrm{a}, \mathrm{b}$ shows the inverse pole figure (IPF) maps of the as-extruded AX212 and AXE20606, which indicate consistent result with the SEM micrographs in Fig. 5 that bimodal microstructure containing fine DRXed grains with relatively random orientation and coarse deformed grains with strong basal texture is obtained in both of the asextruded alloys. The volume fractions and average grain sizes of the DRXed grains in the AX212 and AXE20606 alloys are measured to be $71 \%, 2.3 \mu \mathrm{m}$ and $56 \%, 2.4 \mu \mathrm{m}$, respectively. Additionally, it is interesting to note that the IPF maps can be roughly divided by the well-DRXed regions with red contrast and poorly DRXed regions with 

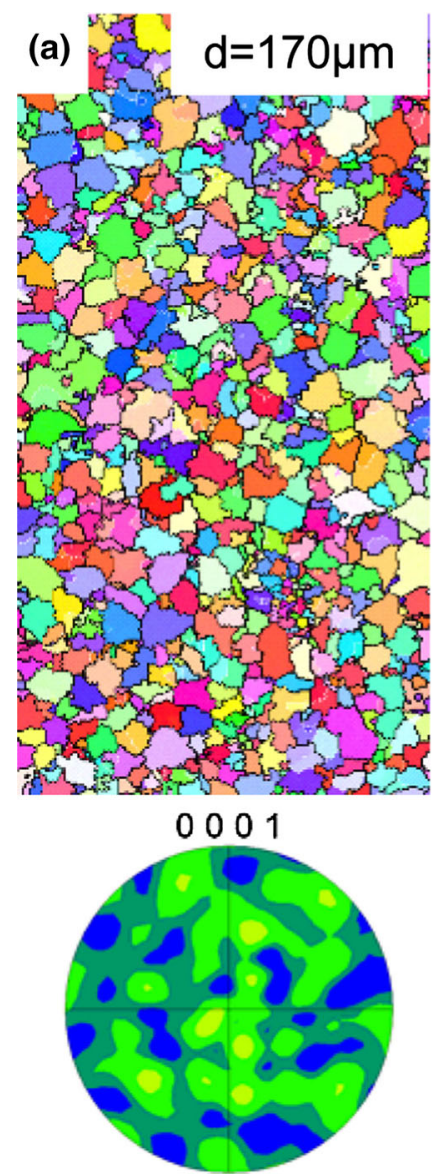

$\operatorname{Max}=2.8$
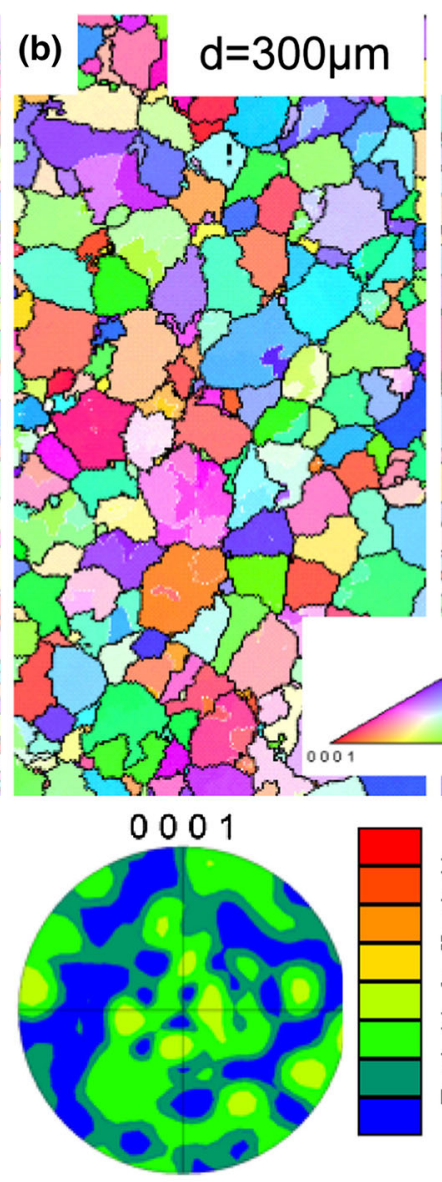

$\operatorname{Max}=3.9$

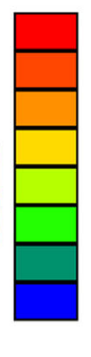

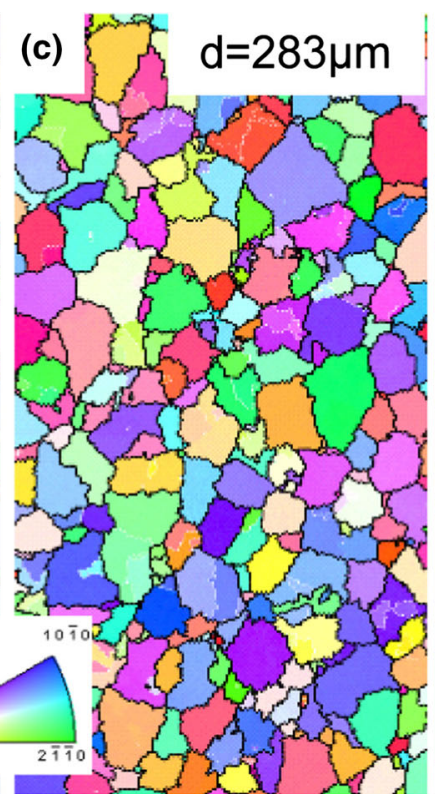

0001

32.000
16.000
8.000
4.000
2.000
1.000
0.500

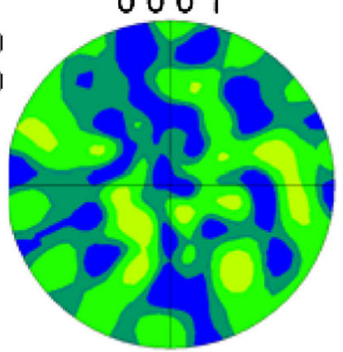

$\operatorname{Max}=3.7$

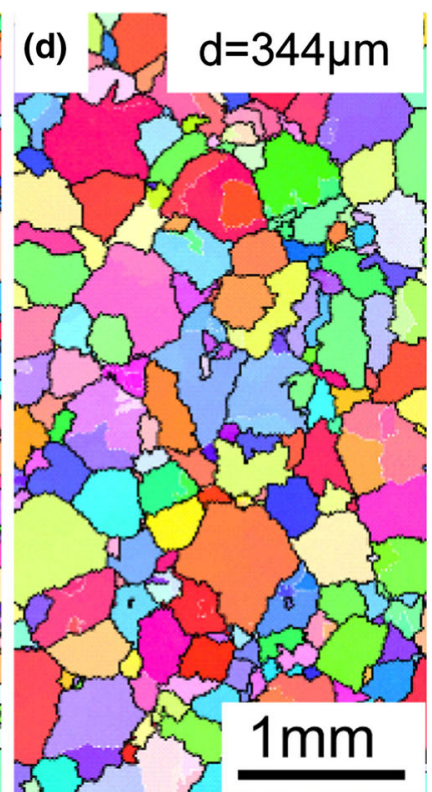

0001

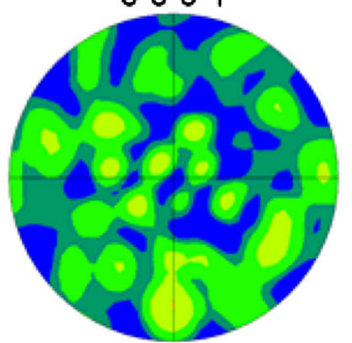

$\operatorname{Max}=4.1$

Fig. 4 IPF maps and corresponding pole figures of the as-cast alloys: a AX212, b AXE2102, c AXE20804, d AXE20606

green contrast, especially in the as-extruded AXE20606, the approximate angles between them are $82^{\circ}-88^{\circ}$, which is supposed that extension twinning occurs at the beginning of the deformation, subsequently, DRX may hardly progress in the twins with high $(0001)<11 \overline{2} 0>$ Schmid factor due to the exclusively activated basal slip of dislocations [32]. Figure 6c, d shows the (0001) and (1010) pole figures of the as-extruded AX212 and AXE20606, respectively; the Schmid factor distributions for $(0001)<11 \overline{2} 0>$ basal slip in these two alloys along the ED is shown in Fig. 6e. The result suggests that the Schmid factor tends to distribute toward lower values in the as-extruded AX212. It can be observed that both alloys exhibit typical basal texture in the extruded Mg alloys [46-48], namely the (0002) basal planes of the $\alpha-\mathrm{Mg}$ array parallel to the ED with their $<10 \overline{1} 0>$ direction orientates to the ED. This restricts basal slip of the dislocations in the extruded alloys, especially in the deformed grains as highlighted by hexagons in Fig. 6a, $\mathrm{b}$, due to the lower $(0001)<11 \overline{2} 0>$ Schmid factor when tensile force is loading the ED. As a result, the alloys can be strengthened by the basal texture.
Meanwhile, it should be noted that the texture intensities of both as-extruded AX212 and AXE20606 are much lower than that of the as-extruded conventional $\mathrm{Mg}$ alloys [46-48]. It is well known that the addition of RE can effectively weaken the basal texture of $\mathrm{Mg}$ alloys that results from the particle stimulated nucleation (PSN) of recrystallization, shear band nucleation and solute drag effect [19, 45, 47, 49]. Laser et al. [19] analyzed the influence of $\mathrm{Ca}$ and $\mathrm{MM}$ on the microstructure evolution of AZ31 alloys during extrusion and concluded that the additions of $\mathrm{Ca}$ and $\mathrm{MM}$ have no effect on the type of the texture, whereas the texture intensities of the Ca- and MMcontaining extruded alloys decrease considerably. The reason should be ascribed to the randomly nucleated DRXed grains at the intermetallic particles and the lower grain boundary mobility caused by the pinning effect of intermetallic particles. Thus, the mechanism of $\mathrm{Ca}$ addition on the texture weakening of the extruded $\mathrm{Mg}$ alloys should be almost same as that of the MM [45]. In this study, it can be seen that the $0.6 \% \mathrm{MM}$ substitution leads to the decrease in the number density of the fragmented phases 

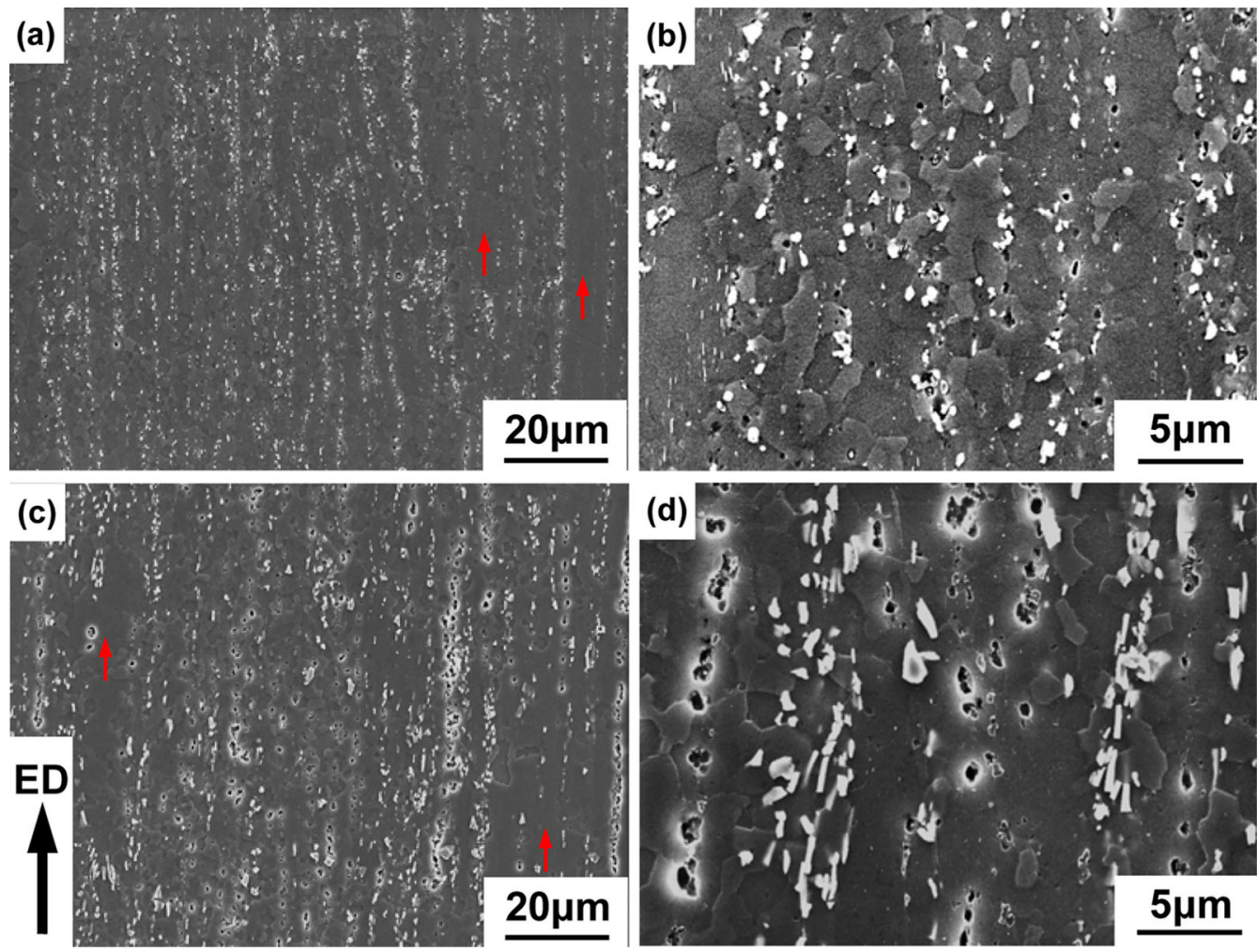

Fig. 5 SEM micrographs of the as-extruded alloys observed on the longitudinal sections: a, b AX212; c, d AXE20606

after hot extrusion; thus, the as-extruded AXE20606 undoubtedly provides few sites for PSN of the DRX and which accounts for the lower DRX volume fraction on one facet. Consequently, the basal texture intensity of the asextruded AXE20606 is stronger than that of the as-extruded AX212.

Figure 7 shows the TEM observations of the fine precipitates in the deformed grains of as-extruded AX212 and AXE20606. As marked by red arrows in Fig. 7a, c, planar precipitates form on the basal plane of the $\alpha-\mathrm{Mg}$ matrix and distribute densely in both of the as-extruded AX212 and AXE20606 during extrusion and subsequent cooling process. The corresponding SAED patterns prove that these precipitates should be $\mathrm{Al}_{2} \mathrm{Ca}$ phases with $\mathrm{C} 15$ structure $(a=0.804 \mathrm{~nm}$, space group $\mathrm{Fd} \overline{3} \mathrm{~m})$ and the orientation relationship between $\mathrm{Al}_{2} \mathrm{Ca}$ and $\alpha-\mathrm{Mg}$ matrix should be $(111)_{\mathrm{Al} 2 \mathrm{Ca}} / /(0001)_{\alpha-\mathrm{Mg}}$ and $[110]_{\mathrm{Al} 2 \mathrm{Ca}} / /[10 \overline{1} 0]_{\alpha-\mathrm{Mg}}[28]$. It is interesting to note that the size of the $\mathrm{Al}_{2} \mathrm{Ca}$ precipitates in the AXE20606 is much finer than that in the AX212 and the number densities of the $\mathrm{Al}_{2} \mathrm{Ca}$ precipitates in the AX212 and AXE20606 are estimated to be $8.2 \times 10^{19} \mathrm{~m}^{-1}$ and $1.5 \times 10^{21} \mathrm{~m}^{-1}$, respectively. Figure $7 \mathrm{~b}, \mathrm{~d}$ shows the high-resolution electron microscope (HREM) micrographs and corresponding FFT of the $\mathrm{Al}_{2} \mathrm{Ca}$ precipitates in the asextruded AX212 and AXE20606, respectively, which also demonstrate that the thickness of the $\mathrm{Al}_{2} \mathrm{Ca}$ precipitate in
AXE20606 is $\sim 2.1 \mathrm{~nm}$, only one-third of that in the $\mathrm{AX} 212$. Furthermore, the strain contrast around the $\mathrm{Al}_{2} \mathrm{Ca}$ precipitate in the AXE20606 is observed to be more obvious than that in the AX212. It is possible that the MM atoms segregate near the $\mathrm{Al}_{2} \mathrm{Ca}$ precipitates and even substitute the $\mathrm{Ca}$ atoms in the $\mathrm{Al}_{2} \mathrm{Ca}$ precipitates, which should be responsible for the strain concentration and restrict the growth of the precipitates. Furthermore, the addition of MM reduces the solid solubility of $\mathrm{Ca}$ and $\mathrm{Al}$ in the $\alpha-\mathrm{Mg}$ matrix thereby promoting the formation of the $\mathrm{Al}_{2} \mathrm{Ca}$ precipitates and make AXE20606 achieve a much higher number density of the $\mathrm{Al}_{2} \mathrm{Ca}$ planar precipitates. Besides of the planar $\mathrm{Al}_{2} \mathrm{Ca}$ precipitates, fine spherical precipitates marked by red arrows can also observed near the $\mathrm{Al}_{2} \mathrm{Ca}$ precipitates and disperse in the $\alpha-\mathrm{Mg}$ matrix, which are supposed to form during the hot extrusion and have been commonly reported to be $\mathrm{Al}-\mathrm{Mn}$ precipitates with the lattice parameter of $\sim 0.457 \mathrm{~nm}$ in the extruded $\mathrm{Mg}-\mathrm{Al}-\mathrm{Ca}-\mathrm{Mn}$ alloys [28, 29, 35].

Figure 8a shows the BF image of the DRXed region in the as-extruded AX212; it can be seen that the fine fragmented eutectic phases pinned at the grain boundaries are $(\mathrm{Mg}, \mathrm{Al})_{2} \mathrm{Ca}$ and $\mathrm{Mg}_{2} \mathrm{Ca}$ based on the corresponding SAED patterns in Fig. 8b, c. Similarly, fragmented $\mathrm{Al}_{2} \mathrm{MM}$ phases are also found to be located at the grain boundaries in the DRXed region in the as-extruded AXE20606 (Fig. 8d, e). The TEM observation determines that the fragmented 


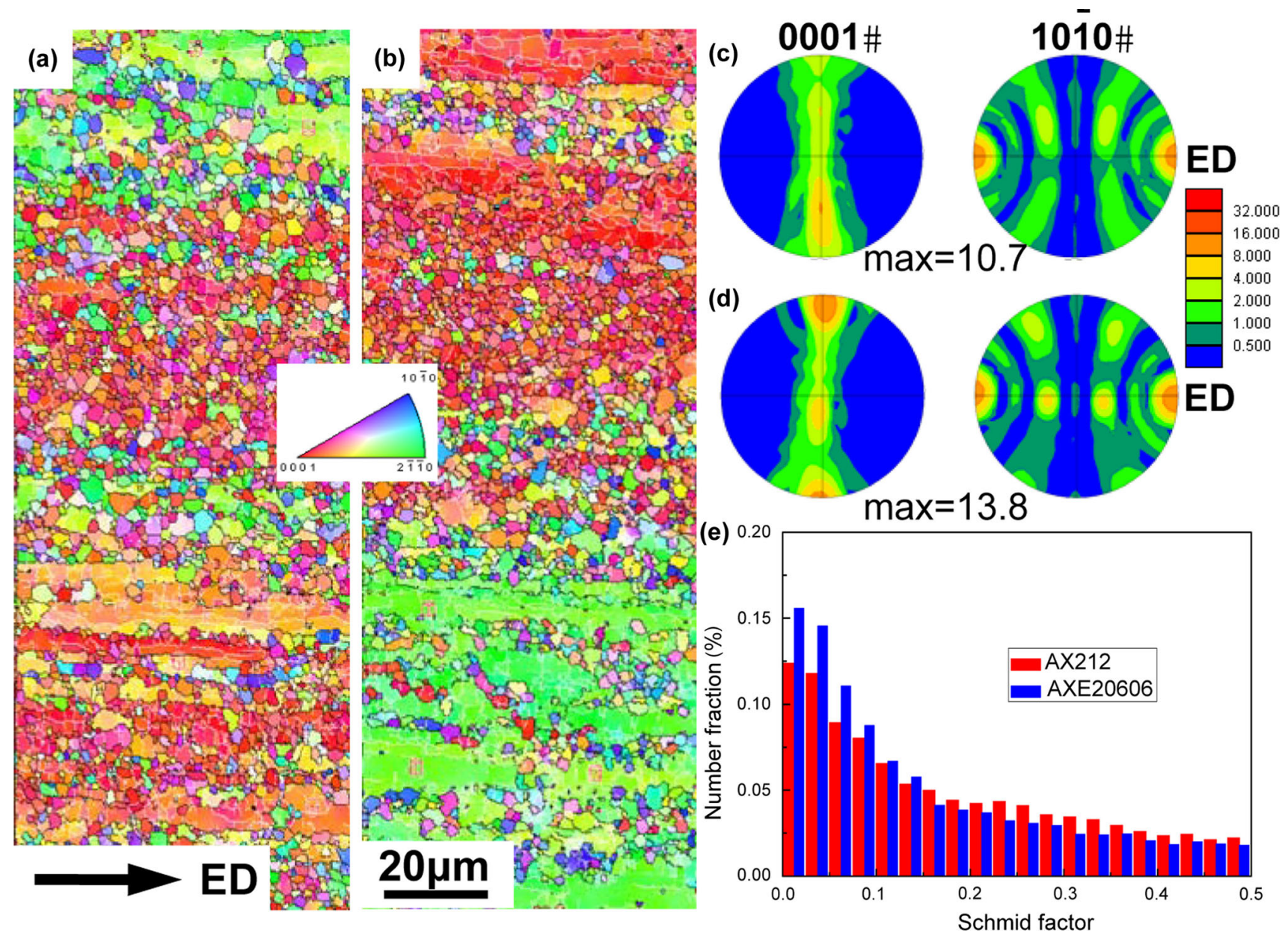

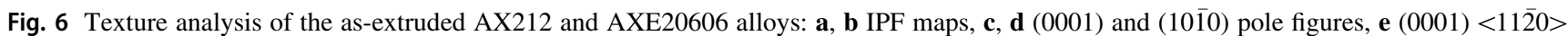
Schmid factor distribution

eutectic phases effectively restrict the grain boundaries to prevent the grain growth during hot extrusion. Comparing the TEM BF images of the DRXed regions (Fig. 8) and coarse deformed grains (Fig. 7), we can know that the nanosized planar $\mathrm{Al}_{2} \mathrm{Ca}$ and spherical $\mathrm{Al}-\mathrm{Mn}$ precipitates marginally appear in the DRXed regions. Figure $8 \mathrm{f}$ shows the magnified $\mathrm{BF}$ image of the area indicated in Fig. 8d, which reveals that the planar $\mathrm{Al}_{2} \mathrm{Ca}$ precipitate pins at grain boundary in the as-extruded AXE20606. It is supposed that the increased number density of the finer $\mathrm{Al}_{2} \mathrm{Ca}$ precipitates in the as-extruded AXE20606 may exert more effective pinning effect on the grain growth than that in the as-extruded AX212. As a consequence, the two alloys show almost no distinction in the average DRXed grain size after extrusion, despite the relative sparse distribution of coarse fragmented MM-containing phases in AXE20606. Additionally, it should be mentioned that since the fine $\mathrm{Al}_{2} \mathrm{Ca}$ and $\mathrm{Al}-\mathrm{Mn}$ precipitates in the $\alpha-\mathrm{Mg}$ matrix restrict the dislocation motions to hinder the DRX, color variation generally caused by the excessive dislocations and subgrain boundaries can be easily observed in the deformed grains in both of the as-extruded alloys (Fig. 6a, b) [35].

\subsection{Mechanical Properties of the Extruded Alloys}

Figure 9a shows the nominal tensile stress-strain curves of the as-extruded alloys tested at room temperature (RT), and the corresponding tensile yield strength (TYS), ultimate tensile strength (UTS) and elongation to failure are summarized in Table 2. The as-extruded AX212-based alloy exhibits high TYS of $353 \mathrm{MPa}$ and good elongation to failure of $12.9 \%$, which is superior to that of the conventional $\mathrm{Mg}$ alloys [46]. At the mean time, it can be found that the MM substitution for $\mathrm{Ca}$ brings about negligible variation in the RT tensile properties. The TYS and elongation to failure of the as-extruded AXE20606 are $352 \mathrm{MPa}$ and $12.8 \%$, respectively.

The reason may be elucidated through the discussion of the strengthening mechanism of the as-extruded alloys: (1) 

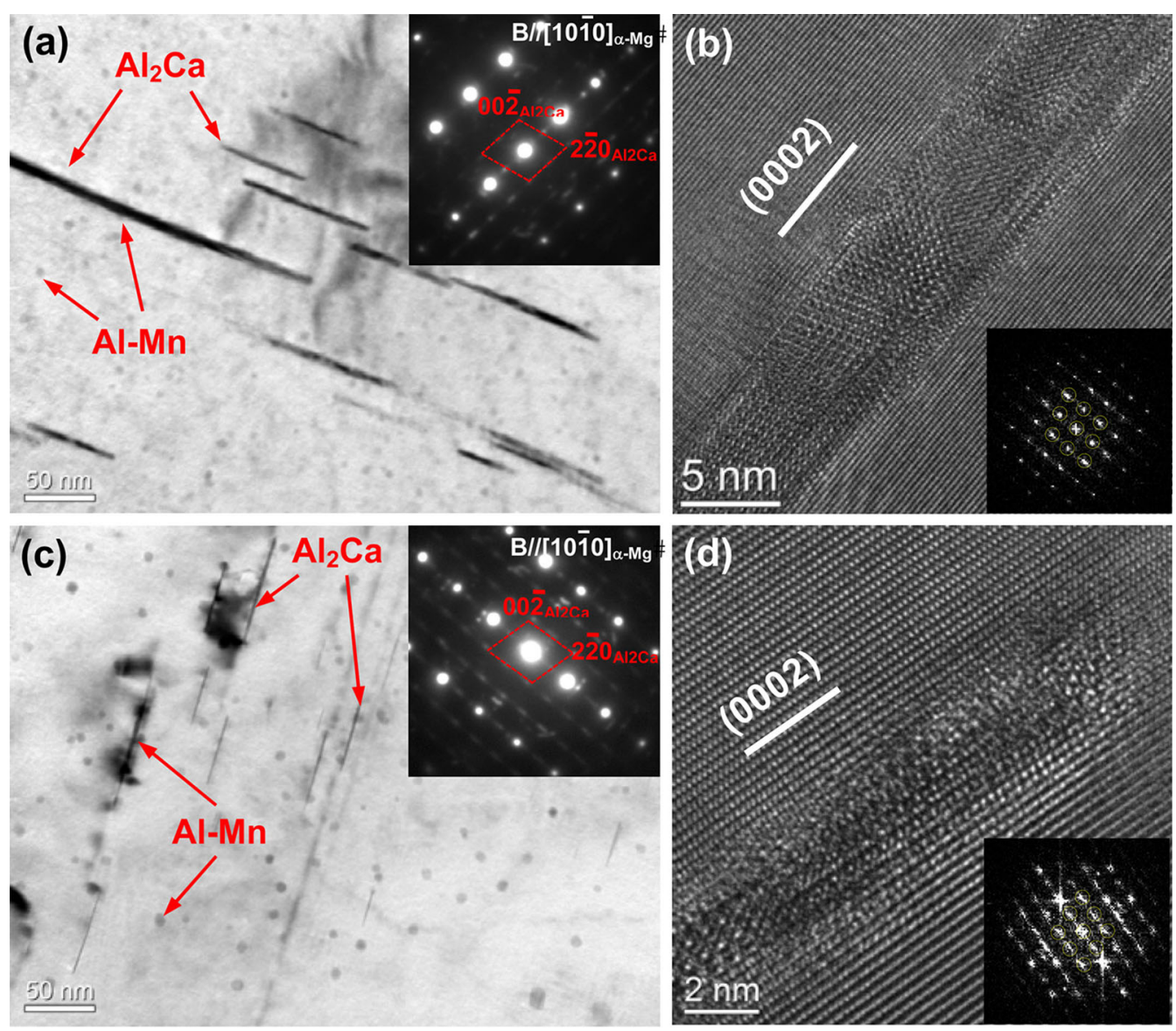

Fig. 7 TEM observations of the precipitates in the deformed region of the as-extruded AX212 and AXE20606 alloys: a, c BF images and SAED patterns, b, d HREM images taken from $[10 \overline{10}]_{\alpha-\mathrm{Mg}}$ and corresponding FFT of the $\mathrm{Al}_{2} \mathrm{Ca}$ precipitates with $\mathrm{C} 15$ structure

grain boundary strengthening, fine DRXed grains obtained during hot extrusion in this study can enhance the yield strength according to the Hall-Petch relationship; however, due to the little difference in the average DRXed grain sizes of the two extruded alloy, the grain boundary strengthening may contribute equally to the strength in the AX212 and AXE20606; (2) texture strengthening, the asextruded alloys exhibit basal texture with (0002) basal planes aligned along the ED; thus, when tensile loading is performed along the ED, the basal slip of the dislocations will be suppressed due to the low $(0001)<1120>$ Schmid factor and the alloys will be strengthened. Because the AXE20606 shows stronger texture intensity and lower Schmid factor than those of the as-extruded AX212 (Fig. 6), the yield strength of the as-extruded AXE20606 will be definitely improved more effectively than that the as-extruded $\mathrm{AX} 212$; (3) precipitation strengthening, nanosized planar $\mathrm{Al}_{2} \mathrm{Ca}$ and spherical $\mathrm{Al}-\mathrm{Mn}$ precipitates formed during the extrusion can effectively hinder the dislocation mobility to strengthen the alloys, especially for the planar $\mathrm{Al}_{2} \mathrm{Ca}$ precipitates formed on the basal plane of the $\alpha-\mathrm{Mg}$ matrix in the deformed regions with strong basal texture, they can act as short reinforcing fiber when tensile force loading along the ED. Because of the higher number density of the $\mathrm{Al}_{2} \mathrm{Ca}$ precipitates in the as-extruded AXE20606 based on the TEM observations (Figs. 7, 8), precipitation strengthening should contribute more to the strength of the as-extruded AXE20606 than that of the AX212 in some extent; (4) dispersion strengthening, SEM micrographs of the as-extruded alloys in Fig. 5 reveal that the fragmented phases in the as-extruded AX212 exhibit finer size, denser and more uniform distribution at the DRXed grain boundaries than those in the as-extruded AXE20606. These phases can significantly pin the grain boundary, and decrement in the size and increment in their density lead to a more effective improvement in the yield strength in the as-extruded AX212 [34]. Furthermore, it is noted that the area fraction of the eutectic phases in the AXE2102 is lower than the other alloys, as shown in Fig. 1. As a result, the amount of the fragmented phases should also be lower in the as-extruded AXE2102, which cause lower strength but higher elongation to failure; (5) solid solution strengthening, because both $\mathrm{Ca}$ and $\mathrm{MM}$ (mainly containing $\mathrm{Ce}, \mathrm{La}, \mathrm{Nd}$, Pr elements) have minimal 

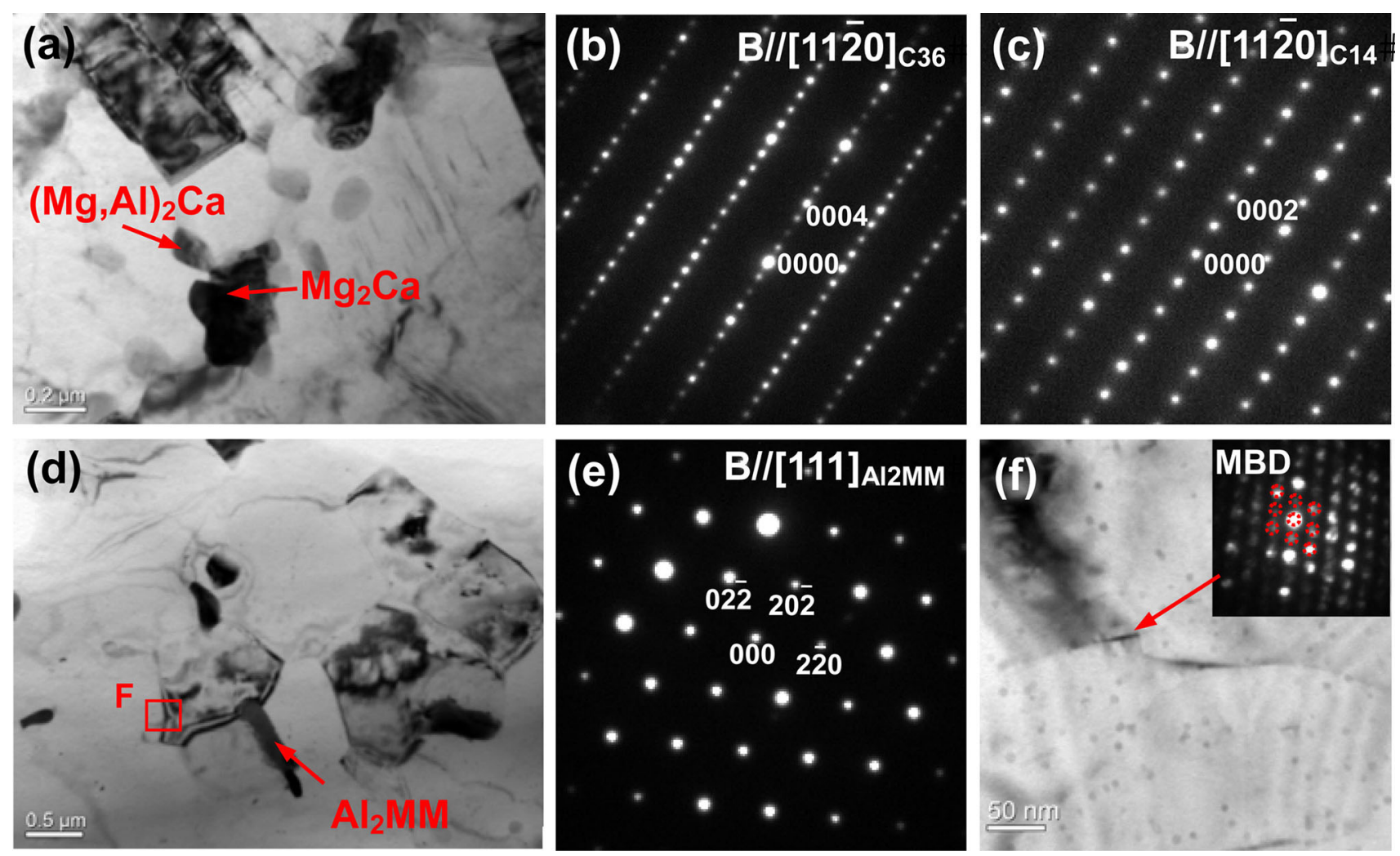

Fig. 8 TEM observations of the compounds distributed in the DRXed regions of the as-extruded alloys: a BF image of the AX212 alloy, b, c SAED patterns of $(\mathrm{Mg}, \mathrm{Al})_{2} \mathrm{Ca}$ and $\mathrm{Mg}_{2} \mathrm{Ca}$, respectively, marked in a, d BF image of the AXE20606 alloy, e SAED pattern of $\mathrm{Al}_{2} \mathrm{MM}$ f magnified region marked in $(\mathbf{d})$
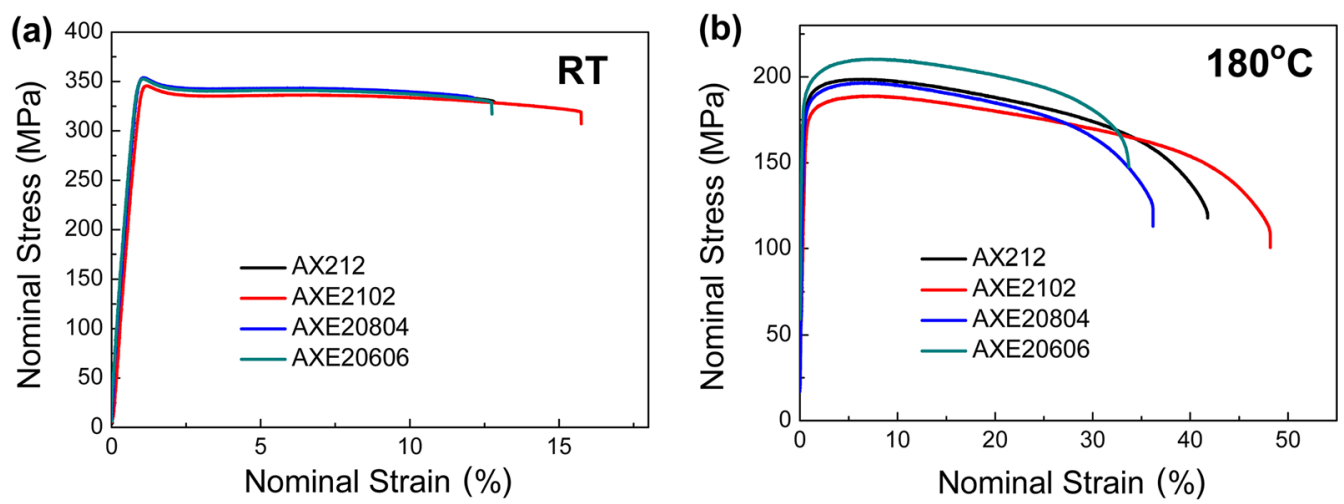

Fig. 9 Nominal tensile stress-strain curves of the as-extruded alloys tested at a RT and $\mathbf{b} 180{ }^{\circ} \mathrm{C}$

Table 2 Tensile properties of the as-extruded alloys at room temperature and $180^{\circ} \mathrm{C}$

\begin{tabular}{|c|c|c|c|c|c|c|}
\hline \multirow[t]{2}{*}{ Alloy } & \multicolumn{3}{|l|}{ RT } & \multicolumn{3}{|l|}{$180{ }^{\circ} \mathrm{C}$} \\
\hline & TYS (MPa) & UTS (MPa) & Elongation (\%) & TYS (MPa) & UTS (MPa) & Elongation (\%) \\
\hline AX212 & $353 \pm 4$ & $353 \pm 3$ & $12.9 \pm 0.5$ & $182 \pm 8$ & $199 \pm 13$ & $41.8 \pm 4.5$ \\
\hline AXE2102 & $345 \pm 3$ & $345 \pm 4$ & $15.7 \pm 0.5$ & $173 \pm 5$ & $189 \pm 9$ & $48.2 \pm 2.7$ \\
\hline AXE20804 & $353 \pm 6$ & $353 \pm 1$ & $12.2 \pm 0.2$ & $178 \pm 7$ & $198 \pm 11$ & $36.2 \pm 3.1$ \\
\hline AXE20606 & $352 \pm 6$ & $352 \pm 3$ & $12.8 \pm 0.3$ & $185 \pm 9$ & $210 \pm 14$ & $33.7 \pm 2.2$ \\
\hline
\end{tabular}


solid solubility in the $\alpha$-Mg matrix; the difference in the strength improvement caused by solid solution strengthening can be ignored. As a consequence, the effect of more effective dispersion strengthening in the as-extruded AX212 is balanced by the more effective texture strengthening and precipitation strengthening in the asextruded AXE20606 and finally, almost identical strengths are obtained in these alloys. It is well known that the refinement of the grain sizes can remarkably shorten the distance of dislocation slip and then release the dislocation pileup to improve the ductility of the alloys, consequently all of the as-extruded alloys show good elongation to failure. More effective strengthening is always accompanied with the poor ductility. The comprehensive strengthenings in the as-extruded alloys caused by the several strengthening mechanisms are similar, so that there is also no obvious discrepancy in the elongation to failure of the as-extruded alloys.

Additionally, it is worthy to note that the well-defined yield point elongation appears in the tensile stress-strain curves tested at RT shown in Fig. 9, which is generally reported in the compression test of $\mathrm{Mg}$ alloys caused by twinning [34, 50]. Stanford et al. [51] also found the yield point elongation in the as-rolled $\mathrm{Mg}-\mathrm{Gd}$ alloys with high Gd concentration during tensile test, and they ascribe it to the locking of dislocations by Gd solute atoms during annealing treatment before tensile test. However, both $\mathrm{Ca}$ and MM have lower solid solubility than $\mathrm{Gd}$ in $\alpha-\mathrm{Mg}$ matrix, especially without any heat treatment; thus, the effect of solute atoms cannot account for that in this study. The yield phenomenon was also observed by Du et al. [52] in the tensile test of the extruded $\mathrm{Mg}-\mathrm{Zn}-\mathrm{Ca}$ alloys, in comparison with their research, fine DRXed grains and fine fragmented phases distributed along the ED are the common points which may take the responsibility of the yield point elongation; the further research concerning its mechanism is necessary and in progress.

High-temperature tensile properties of the as-extruded alloys were evaluated at $180{ }^{\circ} \mathrm{C}$, and the results are shown in Fig. 9b and Table 2. In comparison with the tensile test at RT, the strengths of all the as-extruded alloys decrease at elevated test temperature accompanied with the considerable improvement in the elongation to failure due to the more activated dislocation slip systems at high temperatures. Furthermore, the as-extruded AXE20606 exhibits higher TYS and UTS, but deteriorated ductility than those of the as-extruded AX212, which should be attributed to the fact that the fragmented $\mathrm{Al}_{11} \mathrm{MM}_{3}$ and $\mathrm{Al}_{2} \mathrm{MM}$ phases with better thermal stability can exert more effective pinning on the grain boundaries than $\mathrm{Mg}_{2} \mathrm{Ca}$ and $(\mathrm{Mg}, \mathrm{Al})_{2} \mathrm{Ca}$ phases in the AX212 and perhaps that nanosized planar $\mathrm{Al}_{2} \mathrm{Ca}$ precipitates with segregation of $\mathrm{MM}$ in the AXE20606 would also hinder the dislocations mobility more effectively than those in the AX212. Because of the lowest volume fraction of eutectic phases, the worst tensile strength and superior ductility is achieved in the as-extruded AXE2102.

\section{Conclusions}

Mg-2Al-1.2Ca-0.2Mn-based alloys with MM substitution from 0 to 0.6 at $\%$ were produced by continuous cast method and hot extruded at $400{ }^{\circ} \mathrm{C}$; the effect of MM substitution on the microstructure evolution and mechanical properties was investigated and finally, extruded $\mathrm{Mg}$ alloys with superior mechanical properties at both RT and elevated temperatures were fabricated. The main conclusions are as follows:

1. The as-cast $\mathrm{AX} 212$ is composed of $\alpha-\mathrm{Mg}$ matrix, $\mathrm{Mg}_{2} \mathrm{Ca},(\mathrm{Mg}, \mathrm{Al})_{2} \mathrm{Ca}$ eutectic phases and scattered $\mathrm{Al}_{8} \mathrm{M}_{5}$ particles, the $\mathrm{MM}$ substitution brings about the formation of $\mathrm{Al}_{11} \mathrm{MM}_{3}, \mathrm{Al}_{2} \mathrm{MM}$ phases and $\mathrm{Al}_{10} \mathrm{MM}_{2} \mathrm{Mn}_{7}$ particles with the absence of $(\mathrm{Mg}, \mathrm{Al})_{2-}$ $\mathrm{Ca}$ phase, which also cause the increase in the grain size of the as-cast alloys.

2. The as-extruded alloys exhibit bimodal microstructure that consists of refined DRXed grains with almost random orientation and coarse deformed grains with strong basal texture. The eutectic phases are broken up and distributed at the DRXed grain boundaries along the ED. The MM substitution makes the fragmented phases have larger size and lower number density, whereas it cause no variation in the texture type and slightly strengthen the basal texture due to the lower volume fraction of DRX. Nanosized planar $\mathrm{Al}_{2} \mathrm{Ca}$ and spherical Al-Mn precipitates form in the as-extruded alloys during hot extrusion, especially in the deformed grains which restrict the DRX process and strengthen the alloys. The MM substitution raises the number density of the $\mathrm{Al}_{2} \mathrm{Ca}$ precipitates and refines them.

3. All of the as-extruded alloys exhibit high tensile strength and good ductility at RT, and the MM substitution induces negligible variation in the tensile properties at RT. Dispersion strengthening is more efficient in the as-extruded AX212, while texture and precipitation strengthening are more effective in the as-extruded AXE20606. The MM substitution improves the strength at the elevated temperature of $180{ }^{\circ} \mathrm{C}$ at the expense of elongation due to the good thermal stability of the $\mathrm{Al}_{11} \mathrm{MM}_{3}$ and $\mathrm{Al}_{2} \mathrm{MM}$ phases.

Acknowledgements This work is supported by JSPS Grant-in-Aid for Young Scientists (B), 16K18266, JST Advanced Low Carbon Technology Research and Development Program (ALCA), 12102886. 


\section{References}

[1] R.Z. Wu, Y.D. Yan, G.X. Wang, L.E. Murr, W. Han, Z.W. Zhang, M.L. Zhang, Int. Mater. Rev. 60, 65 (2015)

[2] X.J. Wang, D.K. Xu, R.Z. Wu, X.B. Chen, Q.M. Peng, L. Jin, Y.C. Xin, Z.Q. Zhang, Y. Liu, X.H. Chen, G. Chen, K.K. Deng, H.Y. Wang, J. Mater. Sci. Technol. 34, 245 (2018)

[3] X. Zhang, K.K. Deng, W.J. Li, H.X. Wang, K.B. Nie, F.J. Xu, W. Liang, Mater. Sci. Eng., A 647, 15 (2015)

[4] G.Q. Li, J.H. Zhang, R.Z. Wu, Y. Feng, S.J. Liu, X.J. Wang, Y.F. Jiao, Q. Yang, J. Meng, J. Mater. Sci. Technol. 34, 1076 (2018)

[5] A.A. Luo, Int. Mater. Rev. 49, 13 (2004)

[6] C. Xu, T. Nakata, K. Oh-ishi, T. Homma, T. Ozaki, S. kamado. Scripta Mater. 139, 34 (2017)

[7] X.S. Wang, X. Lu, D.H. Wang, Mater. Sci. Eng., A 364, 11 (2004)

[8] W.L. Xiao, S.S. Jia, J. Wang, J.L. Wang, L.M. Wang, J. Alloys Compd. 458, 178 (2008)

[9] B.L. Mordike, T. Ebert, Mater. Sci. Eng., A 302, 37 (2001)

[10] S.W. Xu, S. Kamado, T. Honma, Mater. Sci. Eng., A 528, 2385 (2011)

[11] J.H. Zhang, S.J. Liu, Z. Leng, M.L. Zhang, J. Meng, R.Z. Wu, Mater. Sci. Eng., A 528, 2670 (2011)

[12] A. Suzuki, N.D. Saddock, J.W. Jones, T.M. Pollock, Acta Mater. 53, 2823 (2005)

[13] H. Cao, C. Zhang, J. Zhu, G. Cao, S. Kou, R. Schmid-Fetzer, Y.A. Chang, Acta Mater. 56, 5245 (2008)

[14] J.R. TerBush, A. Suzuki, N.D. Saddock, J.W. Jones, T.M. Pollock, Scripta Mater. 58, 914 (2008)

[15] D. Amberger, P. Eisenlohr, M. goken. Mater. Sci. Eng., A 510-511, 398 (2009)

[16] B. Kondori, R. Mahmudi, Mater. Sci. Eng., A 527, 2014 (2010)

[17] J.H. Zhang, P. Yu, K. Liu, D.Q. Fang, D.X. Tang, J. Meng, Mater. Des. 30, 2372 (2009)

[18] K. Su, K. Deng, F. Xu, K. Nie, L. Zhang, X. Zhang, W. Li, Acta Metall. Sin. (Engl. Lett.) 28, 1015 (2015)

[19] D.T. Zhang, M. Suzuki, K. Maruyuma, Acta Metall. Sin. (Engl. Lett.) 19, 335 (2006)

[20] J.H. Zhang, D.P. Zhang, Z. Tian, J. Wang, K. Liu, H.Y. Lu, D.X. Tang, J. Meng, Mater. Sci. Eng., A 489, 113 (2008)

[21] T. Laser, Ch. Hartig, M.R. Nurnberg, D. Letzig, R. Bormann, Acta Mater. 56, 2791 (2008)

[22] L. Shang, I.H. Jung, S. Yue, R. Verma, E. Essadiqi, J. Alloys Compd. 492, 173 (2010)

[23] W.W. Du, Y.S. Sun, X.G. Min, F. Xue, M. Zhu, D.Y. Wu, Mater. Sci. Eng., A 356, 1 (2003)

[24] S.F. Liu, B. Li, X.H. Wang, W. Su, H. Han, J. Mater. Process. Tech. 209, 3999 (2009)

[25] B. Nami, S.G. Shabestari, H. Razavi, Sh Mirdamadi, S.M. Miresmaeili, Mater. Sci. Eng., A 528, 1261 (2011)

[26] W.Q. Zhang, W.L. Xiao, F. Wang, C.L. Ma, J. Alloys Compd. 684, 8 (2016)
[27] D.Q. Wan, J.C. Wang, G.F. Wang, X.Y. Chen, L. Lin, Z.G. Feng, G.C. Yang, Mater. Sci. Eng., A 494, 139 (2008)

[28] T. Homma, S. Nakawaki, S. Kamado, Scripta Mater. 63, 1173 (2010)

[29] T. Homma, S. Nakawaki, K. Oh-ishi, K. Hono, S. Kamado, Acta Mater. 59, 7662 (2011)

[30] D. Liu, J. Song, B. Jiang, Y. Zeng, Q. Wang, Z. Jiang, B. Liu, G. Huang, F. Pan, J. Alloys Compd. 737, 263 (2018)

[31] J.B. Zhang, L.B. Tong, C. Xu, Z.H. Jiang, L.R. Cheng, S. Kamado, H.J. Zhang, Mater. Sci. Eng., A 708, 11 (2017)

[32] S.W. Xu, K. Oh-ishi, S. Kamado, T. Homma, Scripta Mater. 65, 875 (2011)

[33] H. Watanabe, M. Yamaguchi, Y. Takigawa, K. Higashi, Mater. Sci. Eng., A 454-455, 384 (2007)

[34] S.W. Xu, K. Oh-ishi, S. Kamado, H. Takahashi, T. Homma, Mater. Sci. Eng., A 542, 71 (2012)

[35] C. Xu, G.H. Fan, T. Nakata, X. Liang, Y.Q. Chi, X.G. Qiao, T.T. Zhang, M. Huang, K.S. Miao, M.Y. Zheng, S. Kamado, H.L. Xie, Metall. Mater. Trans. A 49, 1931-1947 (2018)

[36] Y. Yan, W. Deng, Z. Gao, J. Zhu, Z. Wang, X. Li, Acta Metall. Sin. (Engl. Lett.) 29, 163 (2016)

[37] L.H. Han, H. Hu, D.O. Northwood, Mater. Lett. 62, 381 (2008)

[38] G. Pettersen, H. Westengen, R. Hoier, O. Lohne, Mater. Sci. Eng., A 207, 115 (1996)

[39] J.L. Wang, N. Shi, L.D. Wang, Z.Y. Cao, L.M. Wang, J.P. Li, J. Rare Earth. 28, 794 (2010)

[40] S.S. Li, W.C. Zheng, B. Tang, D.B. Zeng, X.T. Guo, J. Rare Earth. 25, 227 (2007)

[41] H.T. Son, J.S. Lee, D.G. Kim, K. Yoshimi, K. Maruyama, J. Alloys Compd. 473, 446 (2009)

[42] J.H. Zhang, Z. Leng, M.L. Zhang, J. Meng, R.Z. Wu, J. Alloys Compd. 509, 1069 (2011)

[43] A. Janz, J. Grobner, H. Cao, J. Zhu, Y.A. Chang, R. SchmidFetzer, Acta Mater. 57, 682 (2009)

[44] W.C. Zheng, S.S. Li, B. Tang, D.B. Zeng, Acta Metall. Sin. 42, 835 (2006). (in Chinese)

[45] S.M. Masoudpanah, R. Mahmudi, Mater. Sci. Eng., A 526, 22 (2009)

[46] R.H. Li, F.S. Pan, B. Jiang, H.W. Dong, Q.S. Yang, Mater. Sci. Eng., A 562, 33 (2013)

[47] T. Al-Samman, Mater. Sci. Eng., A 560, 561 (2013)

[48] F. Li, Y. Liu, X. Li, Acta Metall. Sin. (Engl. Lett.) 30, 1135 (2017)

[49] C. Xu, M.Y. Zheng, K. Wu, E.D. Wang, G.H. Fan, S.W. Xu, S. Kamado, X.D. Liu, G.J. Wang, X.Y. Lv, Mater. Sci. Eng., A 559, 615 (2013)

[50] M.R. Barnett, M.D. Nave, A. Ghaderi, Acta Mater. 60, 1433 (2012)

[51] N. Stanford, D. Atwell, M.R. Barnett, Acta Mater. 58, 6773 (2010)

[52] Y.Z. Du, M.Y. Zheng, X.G. Qiao, K. Wu, X.D. Liu, G.J. Wang, X.Y. Lv, M.J. Li, X.L. Liu, Z.J. Wang, Y.T. Liu, Mater. Sci. Eng., A 583, 69 (2013) 